\title{
Print Media Coverage of Women Issues; National and Regional Newspapers of Sindh and the International Perspective
}

\author{
Hadia Khalil \\ Lecturer of Media and Communication Studies \\ Sindh Madressatul Islam University \\ Karachi - Pakistan \\ hadia@smiu.edu.pk \\ $\&$ \\ Dr. Muhammad Osama Shafiq \\ Assistant Professor, \\ Department of Mass Communication, \\ University of Karachi. \\ Karachi - Pakistan \\ osamashafiq@gmail.com
}

\begin{abstract}
Being the fourth pillar of society, media has the responsibility to highlight all the existing issues of society. Women are an integral part of our society and their ratio is continuously increasing in our population. Despite having an equal population ratio, they are facing numerous difficulties in daily routine and those issues are not being highlighted seriously in our media. Due to this, the women in our society suffers a lot. This study aims to find out and compare the coverage by the media to the issues of the women by the National and Regional Newspapers in Sindh and the international perspective related to coverage of women issues. For data collection purpose, three leading newspapers have been selected and previous international researches have been studied to get a clear global perspective. The selected Newspapers includes two national newspapers i.e. Daily Dawn and Daily Jang and one newspaper of regional level that is Daily Kawish. The nature of study is quantitative. For analyzing and collecting data, content analysis and comparative methods have been selected. In this regard the time period of one year has been chosen to collect the data which is from July 2015-June 2016. The most significant finding of this study is that regional newspaper is leading over national newspapers in terms of coverage and space of selected women issues.
\end{abstract}

Keywords: Print Media, Women Issues Coverage, Sindhi Media, Gender issues. 


\section{Introduction}

Women contributes half of the population in Pakistan. As per the 2017 census, women were forty-nine percent of total national population (Pakistan Bureau of Statistics, GOP 2017) and surprisingly a prominent number of them are living their lives below the line of poverty (Saeed, 2013). Although they exist in almost equal numbers of men in our society. Being a prominent member of society, they are still being neglected. The dominance of men in our society is the major reason of this. Unfortunately, women in our society are being discriminated in every arena of life. Due to the absence of basic knowledge about human \& women rights and the tribal structure women are being treated as property of male members in remote areas of our country. These days, workplace harassment and domestic violence is rapidly increasing. Women are being sexually abused, raped and face violence at domestic level and work/public place harassment as quoted by the Human Rights Commission of Pakistan (HRCP annual report 2018).

The province, Sindh is the $2^{\text {nd }}$ biggest region of Pakistan according to population count and it is famous as the land of rich history with reference to its resolutions, social qualities and values. Unfortunately, people practice patriarchy as the basic custom in Sindh. The male dominance is encouraged by the fundamental custom which provides every right to the male member of the family only. Even the male member of a family has right to take decision about the women life. Even the women of family are not allowed to participate in decision making process of family issues.

Even in Sindh women are facing many problems related to their survival; these issues include sexual and domestic level violence, acid attacks and burning them alive, threatened and beaten by male members on domestic issues, gender-based discrimination and honor killings. As per the reports of Madadgar; an NGO, during the year 2010 to 2013, the reported cases about violence against women from Baluchistan were 5285, 10421 from KPK, 56531 from Punjab and 26100 from Sindh. The statistical breakdown with respect to the violence against women is presented in the below table. 
Reported Cases of Violence Against Women from Jan, 2010 to Dec, 2013

\begin{tabular}{|c|c|}
\hline Case Category & Total \\
\hline Murder & 21155 \\
\hline Rape Murder & 4920 \\
\hline Rape & 4866 \\
\hline Gang Rape & 3639 \\
\hline Torture & 17416 \\
\hline Karokari & 10246 \\
\hline Burnt & 3878 \\
\hline Kidnapping & 15070 \\
\hline Police Torture & 4112 \\
\hline Hudood Cases & 1306 \\
\hline Suicide & 12654 \\
\hline Human Trafficking & 1429 \\
\hline Force Marriages & 1517 \\
\hline Vani Cases & 1514 \\
\hline Grand Total & 98337 \\
\hline
\end{tabular}

Source: NGO Madadgar, 2010-2013 
The Province Wise Breakdown of Violence Against Women Cases from 20102013

\begin{tabular}{|c|c|}
\hline Province & Total \\
\hline Punjab & 56531 \\
\hline Sindh & 26100 \\
\hline KPK & 10421 \\
\hline Baluchistan & 5285 \\
\hline Grand Total & 98337 \\
\hline
\end{tabular}

Source: NGO Maddagar, 2010-2013

\section{Global Perspective of Women Issues}

No nation or culture is free from violence or abusive behavior at domestic grounds. A significant number of women across the globe experience violent actions at domestic level. The fear of physical, emotional, psychological, mental, economical and sexual violence is faced by women and young girls even being at home. Related studies have assessed that in between 20 to $60 \%$ of women worldwide have witnessed physical violence from their husbands or relatives (Aurat foundation, 2014). The violence against women is not a new thing occurred to this society, it has its roots from the history. From the decades, women are allotted to men due to the physical short coming, childbearing capacity and economic dependence. Men has been given the responsibilities of being custodian, guard and breadwinners to the women.

Although in recent times, women have become lawyers, physicians, scientist, politicians and bankers but still they have not got freedom from the subjugation chains of culture and tradition. To create awareness about women rights and make women to stand up and raise their voice for women rights, a systematic use of media has been done as a tool of communication. As United Nations has given the essential guidelines about Equality of constitutional rights for women. Due to the uprising pressure of women's groups worldwide, the Violence against Women issue was exclusively presented in 1991 by the Commission on elimination of all types of discrimination against women (CEDAW). 
As a result of that, United Nations Declaration on Elimination of Violence against Women was passed by the UN in 1993 (UN, 1993). Throughout the world, it has been noted that in South East-Asian, Africa and Eastern Mediterranean countries, the violence against women be it physical, sexual or mental by the husbands has more ratio than other countries. Surprisingly, United States of America also has the highest ratio related to female violence. From the reports or data collected it has been observed that the violence against women is prevailing everywhere in world regardless of education, financial conditions and awareness of women rights among females and society (WHO, 2013). Throughout the world, the young girls and women are meeting the issues of sexual abuse and domestic violence in their daily lives and staying quite against it has become a norm in society. Violence against women at domestic level is most destructive and gloomy act. It is the mistreatment which may include physical abuse or beating, psychological, verbal and mental torture, sexual abuse and rape. This type of behavior against women is a real barrier in the growth of society.

\section{The Status of Women and United Nations Commission}

To empower and raise women's status worldwide, there was a dire need to create a platform, for the purpose United nation commission was setup in 1946. But unfortunately, the effort of UN about the status of women and their implementing women's rights did not change the lives of many women, specifically the females of developing nations. To empower women and for eradication of violence against them, 22 countries along with Pakistan, Afghanistan and Iran requested UN to further consider this sensitive issue, which led to the formation of international consensus on strengthening the women rights. In 1967 UN implemented the statement for the eradication of violence against women. That serves as an indication for the United Nations convention which was adopted by UN General Assembly to eradicate all types of discrimination against women in 1979. On September $3^{\text {rd }}$, 1981, a detailed codification on global legal standards for the protection of women came into force. In March 1996, the convention was signed and sanctioned by Pakistan in Benazir Bhutto's era. 
By the collected data all over world, it is revealed that nearly 98 million female children are not attending school. Around 1 of every 3 women including young girls in their life face sexual harassment. Not only this, 1 of every 7 girls are tied to forced marriage even before the age of fifteen, including some of the brides as young as 8 or 9 years. A noticeable thing here is that around $40 \%$ women are in agribusiness while only 3 to $20 \%$ are property owners. Globally, only $20 \%$ females are the landowners (USAID, 2018).

\section{Objectives of The Study}

- To investigate how much space has been given by the national and regional newspapers to the coverage of the women issues.

- To find out the difference of the news coverage regarding women issues between national and regional newspapers.

\section{Hypothesis}

H1. Probably the space given to the women issues in terms of columns is higher in regional newspaper.

$\mathrm{H} 2$. As compared to national newspapers the news of women issues would be greater in regional newspaper.

\section{Problem Statement}

In Pakistan, the women make nearly half of the population. Women being an essential part of the society prominently working in all domains of life. Women are playing their roles in nation building effectively, including taking care of household to the parliament. Despite of playing an important role in society building, women are facing many difficulties and problems to survive in a society. To report such issues many forums have been developed, in which media as the fourth pillar of the state, is one of the most important mediums. Media has the duty to raise and highlight problems and social evils of society. Print media in the form of document has its importance throughout the world including Pakistan. In Pakistan, print 
media publish newspapers not only in national language but in regional languages as well. Newspapers provide coverage to the problems of society but, the women related issues are not being highlighted responsibly in print media. How much coverage is given to women related issues in Pakistani print media? How and what type of news regarding women problems are being covered by national and regional newspapers? These are some of the questions which need to be answered. To study the media and the women related issues is a dire need of time, through such type of researches we will be able to clearly find out how much seriousness newspapers are paying towards women related issues in our society. Along with the role of media, the contribution of social scientist and academia is also very important to uplift the status of women in our society. The findings and results of this study will also useful for the policy makers and can also be used for eradication of all kind of women related issues and violence against women.

\section{Justification of Study}

Almost all research studies cited in the context of this study have documented the urge to investigate that how newspapers are given coverage to the women issues. Raza and Hussain (2016) Suggested a need of detailed and advance research investigation, particularly a comparative study on the issues of women violence. Specifically, honor killing and physical abuse of women. Raza and Hussain (2016) (Soomro,2012) Pinpointed towards the government and NGO's role and collaboration to implement women rights and a detailed research on the problems of women in our society. Hence, the study related to women issues is a need of time (Soomro, 2012).

\section{Significance of Study}

Currently, the violence against women and the news coverage of related to the issues of women is a hot debate all over the world, and media being the fourth pillar of state has the most important duty to highlight the said problems of society. As women playing a significant role in society, media has the duty to provide their issues an equal opportunity to be covered. Coverage of women issues by the 
newspapers in Sindh is a comparative study that will reveal the phenomenon of coverage of news relating women issues. Which will investigate and highlight how media is working to uplift the status of women in our society. This study will address the answer related to the coverage of violence against women issues in Sindh in detail, which will help concerned departments to resolve and take more pertinent actions to provide an equal platform to women related problems in Pakistan.

\section{Literature Review}

Physical and sexual harassment is a human rights violation in all over the world and also a genuine threat to the Pakistani women as well (Critelli, 2012). The results of the study presented that women of young age as compare to older age are more exposed to domestic violence. The observations proved that younger females who are not obeying their in-laws face domestic violence more frequently (Sana Ashraf Chatha, 2014). Women who are not educated and are dependent on their husbands become victims of domestic violence as compared to the working and educated women. The above statement clears that financial contribution of women in housekeeping help reduce the chances to become the victim of domestic violence (Sana, 2014).

Domestic violence may include bashing, using abusive language, hitting by household objects, shouting aloud, suffocating them with hands or pillows, and whipping (Khan, 2013). The fact is that the male dominating mindset in a society is a result of violence against women at domestic level and at public place (Khurram, 2017). A study reveals that the Arabian Gulf newspaper gives coverage of Non-Muslim women more frequent than the news coverage of Muslim women by newspaper (Halim \& Meyers, 2010). The male oriented societies ignore the fundamental right of equality of women (Halim, 2010). The killings or murders of women in Pakistan are mostly connected to the patriarchal mindset of society (Abbasi et al., 2012). 


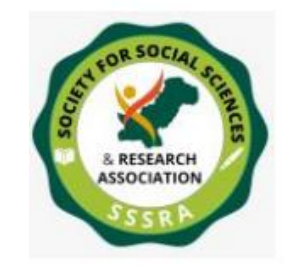

Unfortunately, the act of crime against women is more often carried out by the blood relations and also ignored by the laws and law enforcement organizations. As most of the women are not well educated and well informed about their rights, this situation gives an opportunity for further exploitation of women rights (Soomro, 2012). In the beginning of six months of the year 1992, total 500 women were died because of stove burning and 370 women were killed (Bhatti, 2011).

Women in our society are the most underprivileged gender and this is because of the lack of education and unawareness about their rights. They are even unaware about the basic rights given to them by our religion and the state (Tunio \& Shoukat, 2015). One of the extreme acts of violence against women is honor killing, and acceptance of this act in our society is the proof of patriarchal mindset of society. The tragedy is that this crime is not only prevailing in uneducated and unprivileged setups of rural areas but also in educated families as well, though the rate of this crime is higher in rural areas of Pakistan (Bhanbhro,2013). Different reports of newspapers from the year 2004 to 2005 stated that around two hundred twenty-two women were burnt, in which fifty one percent of cases were accidental and forty nine percent were deliberate act of violence (Nasrullah, 2009).

The factors of domestic violence against women includes lack of knowledge and unawareness of their rights. Also, women in our society are not been given equal chances to participate in different fields of life (Ali,2007). A study reveals that women who are working in private sector are more $\mathrm{u}$ to physical and mental harassment than women working in government sectors. Specifically, the females who are the only job holders of the family usually ignores such abusive behavior at workplace and do not report it for the fear of losing the job (Sadruddin, 2013).

A study reveals that in education system of Sindh, there is a huge discrimination against female children with comparison to male students. Also, the number of female students is much lower than male students (Erum, 2015). In a research study it was stated that in Daily Jang, fifty-six news related to honor killing were reported. In which forty cases were related to females. Similarly, in daily Khabrain contains forty-five news of honor killing, in which thirty-four cases were related to women 
(Raza, 2016). Domestic violence is an act of crime which is usually done by the partners and is considered as a matter of privacy and not reported in front of outsiders (Lloyd, 2017). Usually, women and young girls are not given right to take decision about their life. The male members take decision related to the marriage of female child as well. Females who are having a relationship with male or choosing the life partner by themselves usually becomes the reason of domestic violence (Cavanagh, 2003).

\section{Research Methodology}

This study is quantitative in nature. The content analysis and comparative method is selected for analyzing and collecting data. Keeping in view the nature of this study, news reports of selected categories were collected to analyze the data. With reference to that, six themes of violence against women's news have been carefully chosen. Which includes domestic violence, honor killing, rape, Harassment, acid attack and kidnapping. For data collection, two national and one regional newspaper has been selected. Furthermore, two pages of these newspapers has been used to collect the data i.e. Front page and Back page containing news related to violence against women. Time duration for data collection is from $1^{\text {st }} \mathrm{July} 2015$ to June 30, 2016. For this study, purposive sampling has been applied. For this study, the adopted method are content analysis and comparative method to construct the results from the data collected.

\section{Discussion}

The collected data have been established in the forms of tables. Two types of tables are formulated. First category of the table is showing month wise data related to women issues. And second category of the table shows space given to women issues in terms of columns. As newspapers are considered as a source of authentic data and are in documented form, that is why the researcher has selected this medium of communication. In conclusion, the collected data of selected newspapers were compared. The news coverage of the national newspapers with respect to selected categories of women issues has been compared with the regional 
newspapers. Every selected category for the study was given equal importance while comparing the data. Two days of week were selected for data collection as per the results of pilot study conducted for one week. The data collected from newspapers were considered as secondary source. As, news reports were already published, there were no difficulty faced by researcher regarding ethical designs. Data has been analyzed descriptively. For the purpose of analyzing data statistically, tables have been formulated. Types of tables includes; coverage of women issues given to the selected categories of selected newspaper on designated pages and days of week and how much space has been given to the selected news in terms of columns.

Table No. 01

Coverage of Women Issues by Daily Kawish, July-15 to June-16

\begin{tabular}{|c|c|c|c|}
\hline Month & \multicolumn{2}{|c|}{ Pages } & Grant Total \\
\hline \multirow{2}{*}{ Jul-15 } & Front & 1 & \multirow{2}{*}{23} \\
\hline & Back & 22 & \\
\hline \multirow{2}{*}{ Aug-15 } & Front & 2 & \multirow{2}{*}{16} \\
\hline & Back & 14 & \\
\hline \multirow{2}{*}{ Sep-15 } & Front & 0 & \multirow{2}{*}{13} \\
\hline & Back & 13 & \\
\hline \multirow{2}{*}{ Oct-15 } & Front & 1 & \multirow{2}{*}{12} \\
\hline & Back & 11 & \\
\hline \multirow{2}{*}{ Nov-15 } & Front & 0 & \multirow[b]{2}{*}{5} \\
\hline & Back & 5 & \\
\hline \multirow{2}{*}{ Dec-15 } & Front & 1 & \multirow[b]{2}{*}{5} \\
\hline & Back & 4 & \\
\hline \multirow{2}{*}{ Jan-16 } & Front & 4 & \multirow[b]{2}{*}{12} \\
\hline & Back & 8 & \\
\hline \multirow{2}{*}{ Feb-16 } & Front & 1 & \multirow[b]{2}{*}{13} \\
\hline & Back & 12 & \\
\hline Mar-16 & Front & 0 & 14 \\
\hline
\end{tabular}




\begin{tabular}{|c|c|c|c|}
\hline & Back & 14 & \\
\hline \multirow{2}{*}{ Apr-16 } & Front & 0 & \multirow[b]{2}{*}{13} \\
\hline & Back & 13 & \\
\hline \multirow{2}{*}{ May-16 } & Front & 0 & \multirow[b]{2}{*}{12} \\
\hline & Back & 12 & \\
\hline \multirow{2}{*}{ Jun-16 } & Front & 2 & \multirow[b]{2}{*}{10} \\
\hline & Back & 8 & \\
\hline
\end{tabular}

The Daily Kawish (a Regional Newspaper of Sindh) published total 148 news related to women issues during the year 2015-16. In which only 12 news were given space on front page and other 136 news were published on back page of newspaper.

Table No. 02

Coverage of Women Issues by Daily Dawn, July-15 to June-16

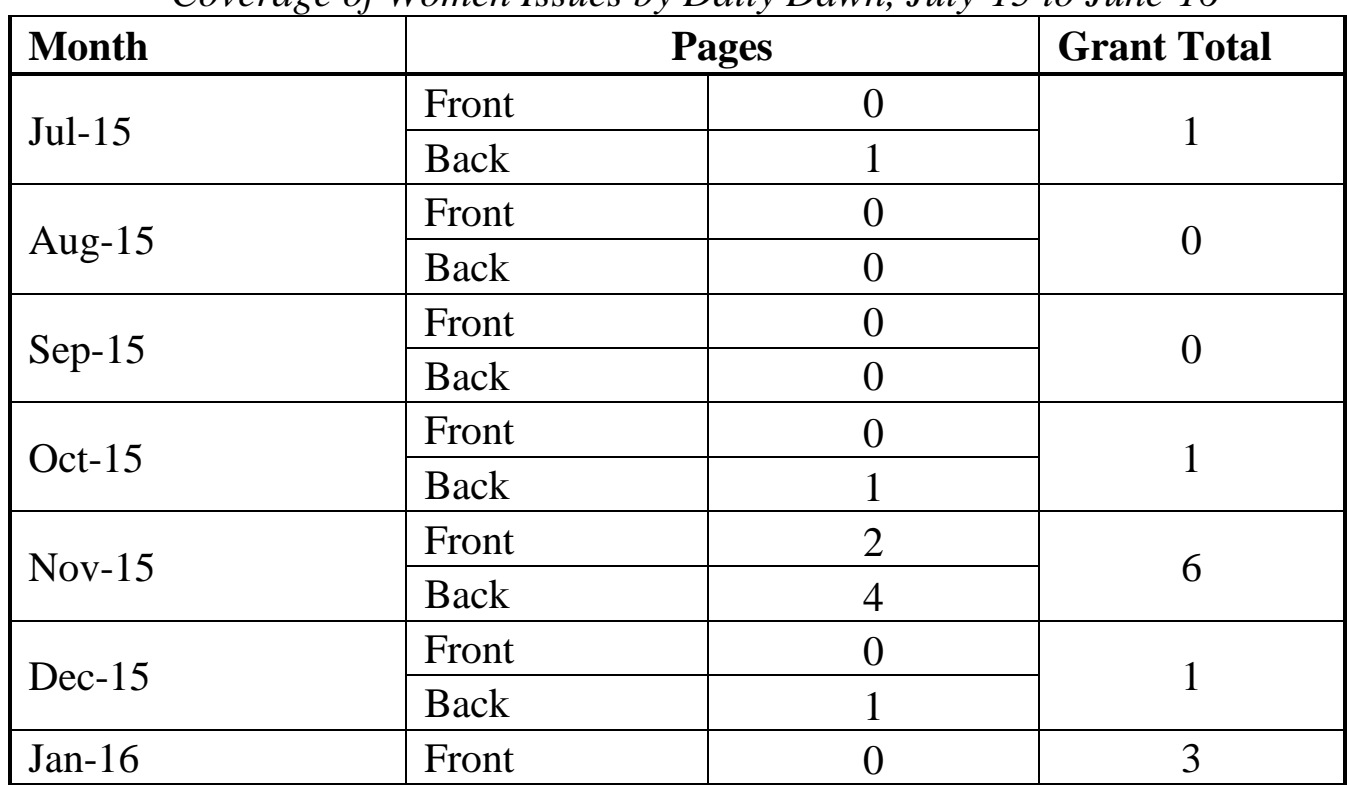




\begin{tabular}{|c|c|c|c|}
\hline & Back & 3 & \\
\hline \multirow{2}{*}{ Feb-16 } & Front & 0 & \multirow{2}{*}{0} \\
\hline & Back & 0 & \\
\hline \multirow{2}{*}{ Mar-16 } & Front & 1 & \multirow{2}{*}{3} \\
\hline & Back & 2 & \\
\hline \multirow{2}{*}{ Apr-16 } & Front & 0 & \multirow{2}{*}{2} \\
\hline & Back & 2 & \\
\hline \multirow{2}{*}{ May-16 } & Front & 0 & \multirow{2}{*}{0} \\
\hline & Back & 0 & \\
\hline \multirow{2}{*}{ Jun-16 } & Front & 0 & \multirow{2}{*}{5} \\
\hline & Back & 5 & \\
\hline
\end{tabular}

The Daily Dawn (a National Newspaper) published total 22 news related to women issues during the year 2015-16. In which only 03 news were given space on front page and other 19 news were published on back page of newspaper.

Table No. 03

Coverage of Women Issues by Daily Jang, July-15 to June-16

\begin{tabular}{|l|l|l|c|}
\hline Month & \multicolumn{2}{|l|}{ Pages } & Grant Total \\
\hline \multirow{2}{*}{ Jul-15 } & Front & 0 & \multirow{2}{*}{2} \\
\cline { 2 - 3 } & Back & 2 & \multirow{2}{*}{7} \\
\hline \multirow{2}{*}{ Sug-15-15 } & Front & 2 & \multirow{2}{*}{1} \\
\cline { 2 - 3 } & Back & 5 & \multirow{2}{*}{1} \\
\hline \multirow{2}{*}{ Oct-15 } & Front & 1 & 1 \\
\cline { 2 - 3 } & Back & 0 & 1 \\
\hline \multirow{2}{*}{ Nov-15 } & Front & 1 & \multirow{2}{*}{1} \\
\cline { 2 - 3 } & Back & 0 & \\
\hline
\end{tabular}




\begin{tabular}{|c|c|c|c|}
\hline & Back & 1 & \\
\hline \multirow{2}{*}{ Dec-15 } & Front & 0 & \multirow{2}{*}{0} \\
\hline & Back & 0 & \\
\hline \multirow{2}{*}{ Jan-16 } & Front & 2 & \multirow{2}{*}{4} \\
\hline & Back & 2 & \\
\hline \multirow{2}{*}{ Feb-16 } & Front & 0 & \multirow{2}{*}{1} \\
\hline & Back & 1 & \\
\hline \multirow{2}{*}{ Mar-16 } & Front & 3 & \multirow{2}{*}{6} \\
\hline & Back & 3 & \\
\hline \multirow{2}{*}{ Apr-16 } & Front & 0 & \multirow{2}{*}{1} \\
\hline & Back & 1 & \\
\hline \multirow{2}{*}{ May-16 } & Front & 0 & \multirow{2}{*}{1} \\
\hline & Back & 0 & \\
\hline \multirow{2}{*}{ Jun-16 } & Front & 2 & \multirow{2}{*}{5} \\
\hline & Back & 3 & \\
\hline
\end{tabular}

The Daily Jang (a National Newspaper) published total 30 news related to women issues during the year 2015-16. In which only 09 news were given space on front page and other 21 news were published on back page of newspaper.

Table No. 04

Coverage of Women Issues by Daily Kawish, July-15 to June-16 with reference to column

\begin{tabular}{|l|l|l|l|c|}
\hline \multirow{2}{*}{ Month } & Pages & $\begin{array}{l}\text { One Column } \\
\text { News }\end{array}$ & $\begin{array}{l}\text { Two Column } \\
\text { News }\end{array}$ & $\begin{array}{l}\text { Three } \\
\text { News }\end{array}$ \\
\hline \multirow{2}{*}{ Jul-15 } & Front & 0 & 1 & 0 \\
\cline { 2 - 5 } & Back & 3 & 10 & 4 \\
\hline Aug-15 & Front & 0 & 0 & 0 \\
\hline
\end{tabular}




\begin{tabular}{|c|c|c|c|c|}
\hline & Back & 5 & 5 & 2 \\
\hline \multirow{2}{*}{ Sep-15 } & Front & 2 & 0 & 0 \\
\hline & Back & 3 & 7 & 3 \\
\hline \multirow{2}{*}{ Oct-15 } & Front & 0 & 0 & 1 \\
\hline & Back & 3 & 3 & 2 \\
\hline \multirow{2}{*}{ Nov-15 } & Front & 0 & 0 & 0 \\
\hline & Back & 1 & 4 & 0 \\
\hline \multirow{2}{*}{ Dec-15 } & Front & 0 & 2 & 0 \\
\hline & Back & 1 & 2 & 1 \\
\hline \multirow{2}{*}{ Jan-16 } & Front & 1 & 0 & 1 \\
\hline & Back & 3 & 7 & 1 \\
\hline \multirow{2}{*}{ Feb-16 } & Front & 0 & 0 & 1 \\
\hline & Back & 2 & 9 & 1 \\
\hline \multirow{2}{*}{ Mar-16 } & Front & 0 & 0 & 0 \\
\hline & Back & 4 & 6 & 0 \\
\hline \multirow{2}{*}{ Apr-16 } & Front & 0 & 0 & 0 \\
\hline & Back & 4 & 6 & 0 \\
\hline \multirow{2}{*}{ May-16 } & Front & 0 & 0 & 0 \\
\hline & Back & 2 & 6 & 2 \\
\hline \multirow{2}{*}{ Jun-16 } & Front & 0 & 0 & 1 \\
\hline & Back & 1 & 6 & 1 \\
\hline
\end{tabular}

The Daily Kawish (a Regional Newspaper of Sindh) given space of one column to total 35 news, two columns space to 74 news and three columns space to 39 news in total.

Table No. 05

Coverage of Women Issues by Daily Dawn, July-15 to June-16 with reference to column 
Print Media Coverage of Women......

\begin{tabular}{|c|c|c|c|c|}
\hline Month & Pages & $\begin{array}{l}\text { One Column } \\
\text { News }\end{array}$ & Two Column News & $\begin{array}{l}\text { Three Column } \\
\text { News }\end{array}$ \\
\hline \multirow{2}{*}{ Jul-15 } & Front & 0 & 0 & 0 \\
\hline & Back & 0 & 2 & 0 \\
\hline \multirow{2}{*}{ Aug-15 } & Front & 0 & 0 & 0 \\
\hline & Back & 0 & 0 & 0 \\
\hline \multirow{2}{*}{ Sep-15 } & Front & 0 & 0 & 0 \\
\hline & Back & 0 & 0 & 0 \\
\hline \multirow{2}{*}{ Oct-15 } & Front & 0 & 0 & 0 \\
\hline & Back & 0 & 1 & 0 \\
\hline \multirow{2}{*}{ Nov-15 } & Front & 0 & 2 & 0 \\
\hline & Back & 2 & 2 & 0 \\
\hline \multirow{2}{*}{ Dec-15 } & Front & 0 & 0 & 0 \\
\hline & Back & 1 & 0 & 0 \\
\hline \multirow{2}{*}{ Jan-16 } & Front & 0 & 0 & 0 \\
\hline & Back & 2 & 1 & 0 \\
\hline \multirow{2}{*}{ Feb-16 } & Front & 0 & 0 & 0 \\
\hline & Back & 0 & 0 & 0 \\
\hline \multirow{2}{*}{ Mar-16 } & Front & 0 & 1 & 0 \\
\hline & Back & 0 & 2 & 0 \\
\hline \multirow{2}{*}{ Apr-16 } & Front & 0 & 0 & 0 \\
\hline & Back & 0 & 2 & 0 \\
\hline \multirow{2}{*}{ May-16 } & Front & 0 & 0 & 0 \\
\hline & Back & 0 & 0 & 0 \\
\hline \multirow{2}{*}{ Jun-16 } & Front & 0 & 0 & 0 \\
\hline & Back & 0 & 4 & 0 \\
\hline
\end{tabular}

The Daily Dawn (a National Newspaper) given space of one column to total 05 news, two columns space to 17 news and no news of three columns space was published. 
Table No. 6

\begin{tabular}{|c|c|c|c|c|}
\hline Month & Pages & $\begin{array}{l}\text { One Column } \\
\text { News }\end{array}$ & $\begin{array}{ll}\text { Two } & \text { Column } \\
\text { News } & \\
\end{array}$ & $\begin{array}{ll}\text { Three } & \text { Column } \\
\text { News } & \\
\end{array}$ \\
\hline \multirow{2}{*}{ Jul-15 } & Front & 0 & 0 & 0 \\
\hline & Back & 0 & 2 & 0 \\
\hline \multirow{2}{*}{ Aug-15 } & Front & 0 & 1 & 1 \\
\hline & Back & 3 & 2 & 0 \\
\hline \multirow{2}{*}{ Sep-15 } & Front & 0 & 0 & 0 \\
\hline & Back & 1 & 0 & 0 \\
\hline \multirow{2}{*}{ Oct-15 } & Front & 0 & 0 & 0 \\
\hline & Back & 0 & 0 & 1 \\
\hline \multirow{2}{*}{ Nov-15 } & Front & 0 & 0 & 0 \\
\hline & Back & 0 & 1 & 0 \\
\hline \multirow{2}{*}{ Dec-15 } & Front & 0 & 0 & 0 \\
\hline & Back & 0 & 0 & 0 \\
\hline \multirow{2}{*}{ Jan-16 } & Front & 0 & 1 & 1 \\
\hline & Back & 1 & 1 & 0 \\
\hline \multirow{2}{*}{ Feb-16 } & Front & 0 & 0 & 0 \\
\hline & Back & 0 & 1 & 0 \\
\hline Mar-16 & Front & 0 & 3 & 0 \\
\hline
\end{tabular}




\begin{tabular}{|l|l|l|l|l|} 
& Back & 2 & 1 & 0 \\
\hline \multirow{2}{*}{ Apr-16 } & Front & 0 & 0 & 0 \\
\cline { 2 - 5 } & Back & 0 & 1 & 0 \\
\hline \multirow{2}{*}{ May-16 } & Front & 0 & 0 & 0 \\
\cline { 2 - 5 } & Back & 0 & 0 & 1 \\
\hline \multirow{3}{*}{ Jun-16 } & Front & 0 & 2 & 0 \\
\cline { 2 - 5 } & Back & & & 0 \\
\hline
\end{tabular}

Coverage of Women Issues by Daily Jang, July-15 to June-16 with reference to column

The Daily Jang (a National Newspaper) given space of one column to total 09 news, two columns space to 17 news and 04 news of three columns space was published.

\section{Testing of Hypothesis}

\section{Hypothesis 1:}

Ho: Probably the space given to the women issues in terms of columns is not higher in regional newspaper.

$\mathbf{H}_{\mathrm{A}}$ : Probably the space given to the women issues in terms of columns is higher in regional newspaper.

In this study the researcher has compared the space given to selected women issues in terms of columns by the selected national and regional dailies. The data revealed that; the regional newspaper has given more space to women issues as compared to national newspapers. Hence, the data rejected the null hypothesis.

\section{Hypothesis 2:}


Ho: As compared to national newspapers the news of women issues would not be greater in regional newspaper.

$\mathbf{H}_{\mathrm{A}}$ : As compared to national newspapers the news of women issues would be greater in regional newspaper.

In this study the researcher has compared the news coverage of the number of news items related to selected women issues in selected national and regional news dailies. The collected data revealed that regional newspaper provide more coverage to the women issues as compared to national dailies. Resultantly, the null hypothesis is rejected.

\section{Conclusion}

This study under the title "Print Media Coverage of Women Issues; National and Regional Newspapers of Sindh and the International Perspective" has been conducted to investigate how much news coverage is been given to women issues and space given to those issues by our national and regional newspapers. The study by nature is quantitative. Daily Jang and Daily Dawn were selected as national newspapers. Whereas, on regional level Daily Kawish was selected. Six categories related to violence against women has been selected for data collection. For data collection front and back pages of Saturdays and Sundays were selected from the selected newspapers. Hence, the hypothesis proved that regional newspaper has given more space and coverage to the women issues, the apparent reason for that is regional newspaper has a lesser area to cover geographically, and have much space for local news in comparison to national newspapers. It is rightly said that, media has the power to influence people, build public opinion and bring change in society. Theories of mass communication such as Magic Bullet and Agenda Setting defines how much direct and indirect influence media has on people in changing their mindset and mold public opinion to get desired results related to any topic. The feminist movement which consist of resistance or any type of conflict using different forums. Those forums might include a social platform, on individual ground or any kind of financial discrimination which might be an obstacle for women, and anything that is being done because of the gender. The results and data of this study supports the feminist theory in the idea of using media as a platform. 
As media is considered a bridge between public and policy makers and have the responsibility to highlight the issues of society weather those issues are on individual grounds, social, economic issues and gender discrimination.

\section{Limitations of the Study}

This study restricted to only three newspapers including Daily Jang, Daily Dawn and Daily kawish because of the limited resources and time. The time period for data collection was a year i.e. 2015-16. As this study confined to the Sindh region, therefore, this should not be generalized for all over Pakistan.

\section{Recommendations}

In the light of observation, findings and conclusion few suggestions and recommendations are given as under:

1. It is suggested that women issues should be given more space and coverage in national newspapers. As national newspapers have more circulation than regional dailies which are only limited to a specific area or region.

2. It is recommended that English newspapers should also provide sufficient news coverage to the issues related to women. Because the English dailies are more read by the officials, policy makers and Bureaucrats.

3. It is also recommended that, women related news should be given space on front pages of newspapers, as they are the equal important section of our society.

4. From the observation, it is suggested that the identity of victims should be kept confidential. The photographs and names of victims of violence should not be published.

5. While reporting news stories of violence against women, instead of using slang language, a proper journalistic language with simple words should be adopted.

6. It is recommended that the photographs of acid attack's and rape victims should not be published in newspapers. 


\section{References}

Abbasi, W. A., Narejo, N. B., \& Soomro, S. (2012). Female Victims of Murder in Sindh: Cultural Criminological Perspective. The Government-Annual Research Journal of Political Science.1(01).

Aurat, Foundation. (2014). Violence against women. Pakistan: Aurat Publication and Information Service Foundation. https://www.af.org.pk/vaw-reports.php.

Bhanbhro, S., Wassan, M. R., Shah, M., Talpur, A. A., \& Wassan, A. A. (2013). Karo Kari: the Murder of Honor in Sindh Pakistan: An Ethnographic Study. International Journal of Asian Social Science. 3(7), 1467-1484.

Bhatti, N., Jamali, M. B., Phulpoto, N. N., Mehmood, T., \& Shaikh, F. M. (2011). Domestic violence against women: A Case Study of District Jacobabad, Sindh Pakistan. Asian Social Science. 7(12), 146.

Cavanagh, J. T., Carson, A. J., Sharpe, M., \& Lawrie, S. M. (2003). Psychological Autopsy Studies of suicide: A Systematic Review. Psychological Medicine, 33(3), 395-405.

Chatha, S. A., Ahmad, K., \& Sheikh, K. S. (2014). Socio-economic status and Domestic Violence: A Study on married women in urban Lahore, Pakistan. South Asian Studies. 29(1), 229.

Critelli, F. M., \& Willett, J. (2013). Struggle and Hope: Challenging Gender Violence in Pakistan. Critical Sociology, 39(2), 201-221.

Domestic Violence. Prevention and protection Bill 2009. http://www.ncsw.gov.pk/previewhighlights/66. 
Halim, S., \& Meyers, M. (2010). News Coverage of Violence Against Muslim Women: A View from the Arabian Gulf. Communication Culture \& Critique. 3(1), 85-104.

Human Right Commission of Pakistan. (2015, September 14). Monthly Jehd-e-Haq جهد http://hrcp-web.org/hrcpweb/.

Khan, H. M., Sindher, R. H., \& Hussain, I. (2013). Studying the Role of Education in Eliminating Violence against Women. Pakistan Journal of Commerce and Social Sciences, 7(2), 405-416.

Khurram, E. (2017). Factors that Contribute to the Violence against women: A Study from Karachi. (Masters Thesis). Peace and Development Studies. https://www.divaportal.org/smash/record.jsf?pid=diva2\%3A1141245\&dswid=86 $\underline{99}$

Lloyd, M., \& Ramon, S. (2017). Smoke and Mirrors: UK Newspaper Representations of Intimate Partner Domestic Violence. Violence Against Women, 23(1), 114-139.

Nasrullah, M., \& Muazzam, S. (2009). Newspaper Reports: A Source of Surveillance for burns among women in Pakistan. Journal of Public Health, 32(2), 245-249.

Nations, U. (1993). Declaration on Elimination of Violence against Women. USA: United Nations.

https://www.ohchr.org/EN/ProfessionalInterest/Pages/ViolenceAgainstWomen.as $\underline{p x}$

Pakistan Bureau of Statistics. (2017, June). Monthly Bulletin of Statistics. http://www.pbs.gov.pk/ 
Poverty illiteracy termed causes of domestic violence. (2006, March, 04). Daily Dawn https://www.dawn.com/news/181469

Raza, S., \& Hussain, S. (2016). News Coverage of Physical Violence against Women: Where Do We Position. Journal of Culture, Society and Development, 19, 75-81.

Sadruddin, M. M. (2013). Sexual Harassment at Workplace in Pakistan-Issues and Remedies about the Global Issue at Managerial Sector. Journal of Managerial Sciences, 7(1).

Saeed, H. (2013, April 14). Poverty has a women's face. Daily Dawn. http://dawn.com/2013/04/14/poverty-has-a-womans-face-2/.

Soomro, S., Shah, N. A., Jamali, K., \& Shah, S. A. A. (2012). Status of Women in Sindh. The Women-Annual Research Journal of Gender Studies. 4.

Tunio, S., \& Shoukat, G. (2015). Role of Television in Awareness of Women Rights among Women Folk with Special Focus on Women of District. Naushahro Feroze. Studies, 4(1).

USAID. From the American People. (2018). Gender Equality Program. USA: United States Agency for International Development. https://www.usaid.gov/whatwe-do/gender-equality-and-womens-empowerment. 